\title{
Working with Nonprofit Organizations in Community Settings: Fundraising Strategies for your Organization
}

Elizabeth B. Bolton and Anna Guest-Jelley

\section{Special Relationships}

What special relationships do you plan to develop or cultivate in preparation for your fundraising effort? List who they are and what their relationship is to your organization. These could be with individuals and/or organizations. Remember that "money is not given; it has to be raised" (Greenfield, 2001, p. 397). Cultivating these relationships will take time, but doing so is an integral part of fund raising.

\section{Financial Goals}

List each of your financial goals and the cost to reach each one. You may wish to designate separate goals for different aspects of the nonprofit organization.

\section{Case for Support}

Building on the idea that "money is not given, it has to be raised," the organization will need to build a case for support. The case for support "is both an intellectual conviction and an actual document to be shared with the public" (Greenfield, 2001, p. 398). In other words, it contains the reasons why the organization's current and future stakeholders should contribute to the organization financially. The case for support typically includes statements on some or all of the following:

- Description of your organization

- Purpose and mission

- Services/programs you provide

- Target population you serve

- Philosophy/values

- Geographic area you reach

- Social problem you address

- Strengths that qualify your organization to address the problem

- Challenges you face as an organization

- How you plan to address these challenges

- Estimated costs and time for these costs

- Benefits to clients, community, and society

1. This publication is FCS9252, one of a series of the Department of Family, Youth and Community Sciences, Florida Cooperative Extension Service, Institute of Food and Agricultural Sciences, University of Florida. First published: June 2009. Please visit the EDIS Web site at http://edis.ifas.ufl.edu. Reviewed June 2012.

2. Elizabeth B. Bolton, Ph.D., professor of Community Development, Department of Family, Youth and Community Sciences; Florida Cooperative Extension Service; Institute of Food and Agricultural Sciences; University of Florida; Gainesville, Florida 32611 - 0310; and, Anna Guest-Jelley, MFYCS, MA, director of Violence Prevention Program, Peaceful Paths Domestic Abuse Network, also of Gainesville, FL. 
You have already addressed many of these if you have been working through this guide to building the nonprofit organization. Now you can add that information into your case for support. If you have not yet formulated most of these statements, begin to think about them now in this context as well as in the broader framework of the organization.

\section{Identifying Strategies}

Each nonprofit organization will choose the best combination of fundraising strategies based on its foreseeable resources. Most nonprofits utilize a combination of the three major types of giving: annual, major, and estate. Annual giving includes giving campaigns, membership drives, and direct mailings; major includes endowments and major gifts from individuals/businesses; estate includes planned gifts. (Greenfield, 2001, p. 394)

The organization can choose from one or more of the following possible strategies:

- Member solicitation: Money from membership fees

- Contributions beyond dues: Direct contributions

- Special appeals: For specific purposes

- Acquisition mailings: From people other than members

- Special events: Specific to organization or issue

- Capital campaigns: For larger donations

- Planned Giving: Can be introduced anytime

- Income from program and/or services: Many nonprofits utilize this

- Other-identify: Up to you - this is a good time to utilize the creativity and expertise of board members, staff, and volunteers!

Other ways donors can contribute can be through gifts of equity:

- Bonds and securities

- Property

- Royalties, copyrights, and trademark rights

- Insurance policies naming the organization as beneficiary (Greenfield, 2001, p 412)

\section{Identifying Potential Donors}

Keep in mind that fundraising is about making and keeping relationships with donors, not just about raising funds. If you can cultivate long-term relationships, you will have a more beneficial donor relationship for both the organization and the donor. Consider what groups might be most appropriate for your organization to approach:

- Individual donors

- Corporations

- Foundations

- Government agencies/contracts

- Trade and Professional Associations

- Other-identify

\section{References}

Greenfield, J.M. (2001). Fund-Raising Management. In T. D. Connors (Ed.), The Nonprofit Handbook: Management (pp. 386-431). New York: John Wiley. 